
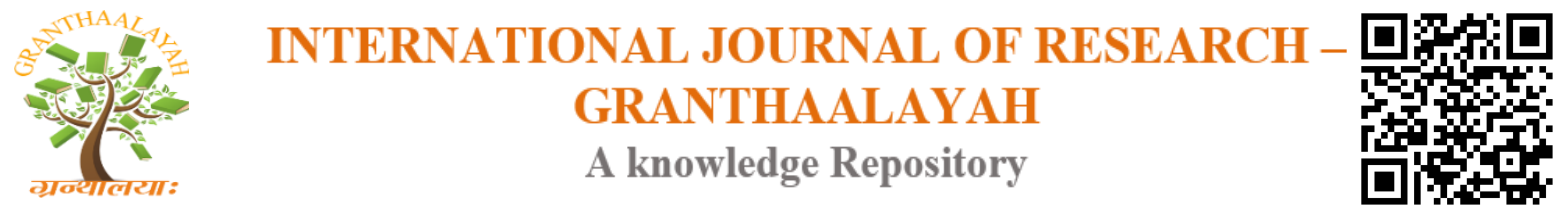

Science

\title{
BIOGAS PRODUCTION FROM RUMINAL BIOMASS OF DIFFERENT GENETIC GROUPS OF SHEEP
}

\author{
Jocélio dos Santos Araújo*1, Francivana Pedrosa Fernandes², Ismael dos Santos Cabral², \\ Michelle de Oliveira Maia Parente ${ }^{1}$, Henrique Nunes Parente ${ }^{1}$, Rosane Claudia Rodrigues ${ }^{1}$ \\ ${ }^{* 1}$ Federal University of Maranhão. Center for Agrarian and Environmental Sciences. Campus of \\ Chapadinha. Road. BR 222, km 4, Postal code 65500-000. Chapadinha, Maranhão/Brazil. \\ ${ }^{2}$ Students in Agricultural Engineering. Federal University of Maranhão
}

\begin{abstract}
The objective was to evaluate the biogas production from ruminal biomass of different genetic groups of sheep. Twelve prototypes of experimental biodigesters were used in batch, which were supplied with ruminal biomass of two genetic groups of sheep (Rabo Largo and Santa Inês) that during a period of confinement were fed with two diets characterized as high and low concentrate, with proportions of $70 \%$ and $30 \%$, respectively. After the animals were slaughtered, all ruminal contents were collected according to the genetic groups and feeding levels, being this the materials that constituted ruminal biomass. A completely randomized design with four treatments and three replications was used. The analyzed variables were temperature, $\mathrm{pH}$, biogas production and pressure. The inoculation of the ruminal biomass of the different genetic groups of sheep studied presented favorable conditions to produce biogas, demonstrating efficiency in the anaerobic digestion process.
\end{abstract}

Keywords: Anaerobic Digestion; Biodigester; Small Ruminants; Solid Waste; Sustainable Systems.

Cite This Article: Jocélio dos Santos Araújo, Francivana Pedrosa Fernandes, Ismael dos Santos Cabral, Michelle de Oliveira Maia Parente, Henrique Nunes Parente, and Rosane Claudia Rodrigues. (2019). "BIOGAS PRODUCTION FROM RUMINAL BIOMASS OF DIFFERENT GENETIC GROUPS OF SHEEP.” International Journal of Research - Granthaalayah, 7(8), 126-132. https://doi.org/10.29121/granthaalayah.v7.i8.2019.646.

\section{Introduction}

For a long time, it used non-renewable energy (oil, gas and coal) As a way to meet the energy needs of the nation. These features that do not have the ability to naturally regenerate, therefore, they are limited and still make a major contribution to the release of greenhouse gases, where the main gases are carbon dioxide $(\mathrm{CO} 2)$, nitrous oxide (N2) and methane (CH4) (Moreira Junior et al., 2017). 
In addition to the environmental problems caused using conventional energy sources, there is another factor that needs special attention waste generated from the slaughter of animals, which are often discarded into the environment without prior treatment. This improper disposal has contributed to the intensification of environmental problems, due to the large amount of waste causing pollution of water sources, air and soil.

To alleviate these problems, emerges as an alternative the use of efficient systems for the treatment of these wastes, that when treated has great potential for energy generation through anaerobic digestion, which is a biological treatment of organic materials, the final product of which is biogas and biofertilizer, which can also represent to the producer, adding value to these products (ElMashad and Zhang, 2010).

In ruminal biomass, whether from sheep, goats or cattle, it contains a significant number of microorganisms capable of degrading nutrients that will undergo metabolic processes which will result in biogas production, which in turn has a great potential for energy generation.

According to Orrico Junior et al. (2012), the feeding of ruminants can influence the biogas production potential, when referring to the nutritional quality that contains the feed offered to animals. Some differences are expected with respect to waste collected from animals receiving concentrated feed from those fed on pasture.

Given the above, the objective was to evaluate the production of biogas from rumen biomass of different genetic groups of sheep.

\section{Materials and Methods}

\subsection{Location and Trial Period}

The experiment was conducted at the Center for Agricultural and Environmental Sciences of the Federal University of Maranhão, located in Chapadinha, MA. The experimental period was from May to June 2018.

\subsection{Sheep Genetic Groups and Animal Management}

The animals consisted of two genetic groups of Rabo Largo and Santa Inês breeds, kept in confinement for 53 days. Forty individual pens were used in the confinement system and 10 sheep were used for each diet, and the feed offered once a day, composed of two diets characterized as high and low concentrate, with proportions of $70 \%$ and $30 \%$, respectively. The source of roughage was Tifton 85 hay (Cynodon dactylon) and the concentrate formulated with corn, soybean meal, wheat bran and mineral mixture.

\subsection{Batch Experimental Biodigesters}

Twelve experimental batch biodigester prototypes were used, made from high density and high molecular weight polyethylene drums, self-locking cap, type NTF 15 , coupled with 1/2" brass P13 gas valve - External NPT x 5/8 internal UNC as described by Araujo el al. (2019). 


\subsection{Experimental Procedure}

Cattle manure was used as an organic substrate, previously diluted in water, in the ratio of 1:1, the mixture being homogenized, using a polyethylene water tank, the mixture is kept at rest for 12 hours. After this period, the biodigester prototypes were supplied in batch, that is, supplied the substrate (mixture of water and cattle manure) and the inoculant (ruminal biomass), in the biodigester only at the beginning of the experiment and filled up to $80 \%$ of the total storage capacity. Hydraulic retention time was 35 days.

Biodigesters were monitored every two days (14:00 PM and 18:00 PM hours) to check for possible leaks and to homogenize the organic substrates and to simulate ruminal movements in order to allow the minimum conditions necessary for anaerobic fermentation and biogas production.

\subsection{Experimental Ruminal Biomass}

After the confinement period, the animals were slaughtered under veterinary inspection and in hygienic and sanitary conditions and collected all ruminal content according to genetic groups and feeding levels, forming a composite sample that was homogenized, which was the material that constituted ruminal biomass, and consequently, experimental treatments. After ruminal biomass sample composition, $10 \%$ of the mixture was added to the biodigester prototypes that already contained the previously prepared organic substrates.

\subsection{Design and Experimental Treatments}

A completely randomized design was used, and the experimental treatments consisted of ruminal biomass inoculation of different genetic groups of sheep that were fed with feeding levels, composed of four treatments and three replications, making a total of 12 experimental units, as follows:

T1 - Ruminal biomass of Rabo Lago group, fed with 70\% concentrate (BRL-70);

T2 - Ruminal biomass of Rabo Lago group, fed with 30\% concentrate (BRL-30);

T3 - Ruminal biomass of the Santa Ines group, fed with 70\% concentrate (BSI-70) and

T4 - Ruminal biomass of the Santa Ines group, fed with $30 \%$ concentrate (BSI-30).

\subsection{Variables Analyzed}

The physical-chemical variables were obtained every seven days: $\mathrm{pH}$ and temperature, with the use of analytical equipment and Multiparameter Meter. The biogas atmospheric pressure (bar) was obtained using a digital manometer, and the amount of biogas $\left(\mathrm{m}^{3}\right)$ produced by treatment was obtained through the GLP/GNV - LAO G 0.6 gasometer, both readings always being taken from 48-hour interval.

\subsection{Statistical Analysis}

The data were submitted to analysis of variance (ANOVA) and when significant the means were compared by Student-Newman-Keuls (SNK) test at 5\% probability. All proposed statistical tests were performed with the aid of SISVAR version 5.6 statistical software (Ferreira, 2011). 


\section{Results and Discussions}

The results obtained for treatment function variables are presented in Table 1 .

Table 1: Mean values of temperature and $\mathrm{pH}$ as a function of experimental treatments

\begin{tabular}{|l|c|c|}
\hline \multirow{2}{*}{ Treatments } & \multicolumn{2}{|c|}{ Variables } \\
\cline { 2 - 3 } & Temperature $\left({ }^{\circ} \mathbf{C}\right)$ & $\mathbf{p H}$ \\
\hline BRL-70 & $28.31^{\mathrm{ns}}$ & $6.50^{\mathrm{ns}}$ \\
\hline BRL-30 & $28.98^{\mathrm{ns}}$ & $6.94^{\mathrm{ns}}$ \\
\hline BSI-70 & $29.73^{\mathrm{ns}}$ & $6.70^{\mathrm{ns}}$ \\
\hline BSI-30 & $28.92^{\mathrm{ns}}$ & $6.88^{\mathrm{ns}}$ \\
\hline Mean & 28.99 & 6.76 \\
\hline CV $(\%)$ & 6.20 & 5.80 \\
\hline P>F & 0.8149 & 0.5519 \\
\hline
\end{tabular}

ns $=$ not significant at $5 \%$ probability. $\mathrm{CV}=$ Coefficient of Variation.

\subsection{Temperature}

There was no significant effect of treatments for the temperature variable. The temperature of the biodigester prototypes of the present work is in the mesophilic range, which varies from $20^{\circ} \mathrm{C}$ to $40^{\circ} \mathrm{C}$, therefore, the averages obtained for this variable, demonstrate that the anaerobic environment was favored in the process of digestion of organic matter and growth of anaerobic microorganisms, especially those producing methane, besides the absence of oxygen, it is essential to maintain temperature stability, since methanogenic bacteria are sensitive to temperature variations.

According to Suryawanshi et al. (2010), this is the appropriate range to produce biogas, as it is where methane-generating bacteria are present, and what probably favored the production of biogas, since the temperature remained throughout the experiment with an average of $28.9^{\circ} \mathrm{C}$. Kumar et al. (2013), also report the importance of temperature in anaerobic digestion performance because it is directly linked to the bacterial metabolic process. However, all bacteria are resistant to rapid temperature changes of up to two hours and can reestablish biogas production when the temperature returns to normal. In a study by Gunnerson and Stuckey (1986), the authors report two optimal digestion regions at $35^{\circ} \mathrm{C}$ in the mesophilic range, which ranges from 20 to $40^{\circ} \mathrm{C}$, and $55^{\circ} \mathrm{C}$ in the thermophilic range, ranging from 40 to $60{ }^{\circ} \mathrm{C}$.

\section{2. $\mathbf{p H}$}

According to the data obtained, the experimental treatments did not statistically influence the $\mathrm{pH}$ variable. The average value was 6.76 , close to neutrality. Thus, these results demonstrate that anaerobic fermentation was favored regardless of the ruminal biomass used in the treatments. The $\mathrm{pH}$ values close to neutrality favor microbial growth, organic matter degradation, biogas production favoring mainly methane producing bacteria. The metabolism of microorganisms is affected when the $\mathrm{pH}$ is acidic, as well as in the alkalinity range, as the extremes decrease methanogenesis, inhibiting methane production. 
These results are corroborated to those presented by Quadros et al. (2010) and Sanchez-Hernandez et al. (2013), where they reported that the range between 6.0 and 8.0 are considered ideal ranges for the development of microorganisms, and the value 7.0 is considered the ideal range. According to Ferreira (2015) methane formation occurs in a relatively narrow $\mathrm{pH}$ range of approximately 6.5 to 8.5 with an optimal range between 7.0 and 8.0. Weiland (2010) reported that the process is severely inhibited if the $\mathrm{pH}$ decreases below 6.0 or increases above 8.5. However, when the $\mathrm{pH}$ decreases, the production of organic acids leads to future $\mathrm{pH}$ reduction by hydrolytic bacteria and may cause the fermentation process to be interrupted (Ferreira, 2015).

The averages obtained for the atmospheric pressure and biogas production variables are presented in table 2 .

Table 2: Mean values of pressure and biogas production as a function of experimental treatments

\begin{tabular}{|l|c|c|}
\hline \multirow{2}{*}{ Treatments } & \multicolumn{2}{|c|}{ Variables } \\
\cline { 2 - 3 } & Pressure (bar) & Production $\mathbf{( m}^{\mathbf{3}}$ ) \\
\hline BRL-70 & $0.09^{\mathrm{ns}}$ & $4.23^{\mathrm{ns}}$ \\
\hline BRL-30 & $0.02^{\mathrm{ns}}$ & $1.88^{\mathrm{ns}}$ \\
\hline BSI-70 & $0.15^{\mathrm{ns}}$ & $7.14^{\mathrm{ns}}$ \\
\hline BSI-30 & $0.22^{\mathrm{ns}}$ & $10.32^{\mathrm{ns}}$ \\
\hline Mean & 0.12 & 5.89 \\
\hline CV $(\%)$ & 154.75 & 138.87 \\
\hline P>F & 0.5990 & 0.6341 \\
\hline
\end{tabular}

$\mathrm{ns}=$ not significant at $5 \%$ probability. $\mathrm{CV}=$ Coefficient of Variation.

\subsection{Biogas pressure}

The inoculation of ruminal biomass of different genetic groups of sheep did not statistically influence biogas pressure. As in the present study a biodigester prototype was used, pressure monitoring was performed to improve equipment operation and efficiency, in addition to analyzing whether the different inoculate used influenced or not in this variable, since biogas pressure is low and not constant due to low energy content due to dilution with various non-combustible gases (Ross et al., 1996). These biogas pressure characteristics are what make it useful as a sustainable energy source.

\subsection{Biogas Production}

Regarding the biogas production variable, there was no significant effect as a result of the experimental treatments. Consequently, ruminal biomass of different genetic groups of sheep did not influence biogas production. It should be noted that the results obtained for the temperature and $\mathrm{pH}$ variables of the present research were considered satisfactory, with values in the ideal range of the contributions in the scientific literature, and this was reflected in the production, which obtained an average of $5.89 \mathrm{~m}^{3}$ of biogas. According to Lucas Junior and Santos (2000) the ruminant waste, undergo a pre-treatment in the digestive tract of animals, which are true natural fermentation chambers where the anaerobic digestion microorganisms are harmoniously developed, therefore, by placing these residues in a biodigester, biogas will soon be produced. 
Otoboni et al. (2016) by analyzing the association of plant waste and waste to perform production tests and quantify biogas, using pilot biodigesters supplied with vegetal residues with a proportion of $10 \%$ in relation to horse, sheep and swine manure, respectively, observed that the volume of biogas production obtained from equine manure was $50 \%$ higher compared to the volume obtained from sheep excretion, but did not obtain biogas production from the swine manure, in which the average values of biogas production obtained from manure. of equine, sheep and swine were $0.032 \mathrm{~m}^{3}, 0.016 \mathrm{~m}^{3}$ and $0.0 \mathrm{~m}^{3}$, respectively. The values obtained by the authors demonstrated that the addition of $10 \%$ of plant residues to the equine manure favored biogas production. It is important to emphasize that the values obtained by the authors were lower when compared with the values obtained in the present research.

Orrico et al. (2011) analyzing the effect of age and different levels of concentrates on goat feeding, observed that biogas production was significant when substrates containing goat droppings with diet at 40:60 volume: concentrate ratio compared to yields in the diet substrates with ratio containing roughage: concentrate ratio 60:40 and 80:20, respectively. They also observed that age also affected biogas production, obtaining higher production with older goats. According to Orrico et al. (2016), when evaluating the dairy cattle manure and waste oil co-digestion, through specific biogas productions, obtained better averages in the doses between 4.4 and $6.5 \%$, with consequent increase in biogas productions and reductions. of solids. In another research by Orrico Junior et al. (2010) when working with the swine manure fed on sorghum, the authors observed that there were significant effects on biogas and methane production.

It should be noted that biogas production, as well as its composition, depends on the efficiency of the anaerobic digestion process, influenced by several factors such as organic load, carbon / nitrogen ratio, $\mathrm{pH}$, pressure and temperature during fermentation, as well as addition of source. from inoculum to manure, which interferes with the microbial population and in the present study, inoculation of ruminal residue from sheep favored biogas production.

\section{Conclusions and Recommendations}

The inoculation of ruminal biomass of the different genetic groups of sheep showed favorable conditions for biogas production, demonstrating efficiency in the anaerobic digestion process.

\section{Acknowledgements}

The authors express their deepest gratitude to the agricultural engineering graduates for their support provided and to Federal University of Maranhão, providing the study.

\section{References}

[1] Araujo, J.S., Cabral, I.S., Meneses, K.C., Coutinho, R.S., Costa, N.A., Araujo, J.V.S. and Cabral, A.S.A. (2019). Batch Biodigester Prototype for Experimental Use. Cross Current International Journal of Agriculture and Veterinary Sciences. 1(3): 67-70.

[2] El-Mashad, H.M., and Zhang, R. (2010). "Biogas production from co-digestion of dairy manure and food waste." Bioresource technology 101(11): 4021-4028. 
[3] Ferreira, C.F. Avaliação da influência da alimentação de biodigestores na produção flexível de biogás. 2015. Dissertação (Mestrado em Ciências Ambientais) - Curso de Pós-Graduação em Meio Ambiente Urbano e Industrial, Setor de Tecnologia, Universidade Federal do Paraná.

[4] Ferreira, D.F. (2011). Sisvar: um sistema computacional de análise estatística. Ciência e agrotecnologia, 35(6): 1039-1042.

[5] Gunnerson, C.G., and Stuckey, D.C. (1986). Anaerobic digestion: principles and practices for biogas systems. World Bank technical paper (No. PB-86-194750/XAB). International Bank for Reconstruction and Development, Washington, DC (USA).

[6] Kumar, K.V., Sridevi, V., Rani, K., Sakunthala, M., and Kumar, C.S. (2013). A review on production of biogas, fundamentals, applications \& its recent enhancing techniques. Elixir Chem Engg, 57: 14073-14079.

[7] Lucas Junior, J. and Santos, T. M. B. (2000). Aproveitamento de resíduos da indústria avícola para produção de biogás. In: Simpósio sobre resíduos da produção avícola, 2000, Concórdia. Anais... Concórdia: CNPSA, pp. 27-43.

[8] Moreira Junior, D.P., Silva, C.M., Bueno, C., Corrêa, S.M. and Arbilla, G. (2017). Determinação de gases do efeito estufa em cinco capitais de diferentes Biomas brasileiros. Revista Virtual de Química, 9(5): 2032-2051.

[9] Orrico, A.C.A., Orrico Junior, P.M.A., and Lucas Junior, J.D. (2011). Biodigestão anaeróbia dos dejetos de cabritos Saanen alimentados com dietas com diferentes proporções volumoso e concentrado. Revista Brasileira de Zootecnia, 40(2): 448-453.

[10] Orrico, A.C.A., Lopes, W.R., Manarelli, D.M., Orrico Junior, P.M.A. and Sunada, N.D.S. (2016). Codigestão anaeróbia dos dejetos de bovinos leiteiros e óleo de descarte. Engenharia Agrícola, 36(3): 537-545.

[11] Orrico Junior, P.M.A., Orrico, A.C.A. and Lucas Júnior, J.D. (2010). Avaliação de parâmetros da biodigestão anaeróbia de dejetos de suínos alimentados com dietas à base de milho e sorgo. Engenharia Agrícola. 30(4): 600-607.

[12] Orrico Junior, P.M.A., Orrico, A.C.A., Lucas Junior, J.D., Sampaio, A.A.M., Fernandes, A.R.M., and Oliveira, E.A.D. (2012). Biodigestão anaeróbia dos dejetos da bovinocultura de corte: influência do período, do genótipo e da dieta. Revista Brasileira de Zootecnia. 41(6): 1533-1538.

[13] Otoboni, A.M.M.B., Xavier, D.O., Giannoni, J.A., Travaglini, M., Nunes, M.M., Jorge, P.S., Pardo. R.B. and Moreira, J.P. (2016). Biodigestão anaeróbia: associação de dejetos animais e resíduos vegetais. Revista Unimar Ciências, 25(1-2): 14-19.

[14] Quadros, D.G., Oliver, A.D.P., Regis, U., Valladares, R., Souza, P.H.F. and Ferreira, E.D.J. (2010). Biodigestão anaeróbia de dejetos de caprinos e ovinos em reator contínuo de PVC flexível, Revista Brasileira de Engenharia Agrícola e Ambiental. 14(3): 326-332.

[15] Ross, C.C., Drake, T.J. and Walsh, J.L. (1996). The handbook of biogas utilization. Environmental Treatment Systems Incorporated.

[16] Sanchez-Hernandez, E.P., Weiland, P. and Borja, R. (2013). The effect of biogas sparging on cow manure characteristics and its subsequent anaerobic biodegradation. International Biodeterioration \& Biodegradation. 83: 10-16.

[17] Suryawanshi, P.C., Chaudhari, A.B. and Kothari, R.M. (2010). Mesophilic anaerobic digestion: first option for waste treatment in tropical regions. Critical reviews in biotechnology. 30(4): 259282.

[18] Weiland, P. (2010). Biogas production: current state and perspectives. Applied microbiology and biotechnology. 85(4): 849-860.

\footnotetext{
*Corresponding author.

E-mail address: jocelios@yahoo.com.br
} 